\title{
Disturbed Australian Spaces: Introduction
}

Salhia Ben-Messahel

\section{(2) OpenEdition}

1 Journals

Electronic version

URL: https://journals.openedition.org/ces/378

DOI: $10.4000 /$ ces. 378

ISSN: 2534-6695

\section{Publisher}

SEPC (Société d'études des pays du Commonwealth)

\section{Printed version}

Date of publication: 30 November 2018

Number of pages: 5-6

ISSN: 2270-0633

\section{Electronic reference}

Salhia Ben-Messahel, "Disturbed Australian Spaces: Introduction", Commonwealth Essays and Studies [Online], 41.1 | 2018, Online since 01 October 2019, connection on 23 August 2021. URL: http:// journals.openedition.org/ces/378; DOI: https://doi.org/10.4000/ces.378

\section{(c) (i) $(9)$}

Commonwealth Essays and Studies is licensed under a Licence Creative Commons Attribution - Pas d'Utilisation Commerciale - Pas de Modification 4.0 International. 


\section{Disturbed Australian Spaces Introduction (for Sue Ryan-Fazilleau)}

Since the beginning of the twenty-first century Australia has entered a phase known as post-reconciliation, which for some artists and writers has marked a turning-point in race relations and issues of belonging to the multicultural society in an Asia-Pacific environment. While post-reconciliation has paved the way for constitutional recognition of Aboriginal and Torres Strait Islander peoples, the effects of settler history can still be perceived in debates on the nation and cultural identity. Recent nationalist claims and cultural tensions raise concerns about the country's ability to overcome the colonial past and fully embrace the multicultural ideal. In his article on recent Australian fiction, Nicholas Birns reminds us that Sue Ryan-Fazilleau, in her extensive study of Peter Carey's work, suggested that the novelist was engaged in a postcolonial quest for identity. Ryan-Fazilleau's valuable contribution to the study of Australian literature is raised in Birns's examination of the works of some twenty-first-century Australian authors and the place of technology in their sense of identity. Birns argues that a new kind of Australian fiction emerged, around 2004, concerned with the temporalities of technology and artifice. He thus shows how indigeneity surfaces in Peter Carey's latest work, and how the legacy of Indigenous dispossession affects, in fact, the global and modern nation. Indigenous spirituality and the importance of place also surface through John Clement Ball's piece on Tim Winton's surfing novel, Breath (2008). Ball considers previous work on Winton's novel and brings a new insight into ecocritical writing by drawing on risk-theory and the sociology of surfing. The focus on the environment and climate change, issues that are central to Winton, extends to the novel's engagement with the ethics and aesthetics of surfing. Ball shows how the ocean and the world of surf are oikos, home and territory, and argues that the surfing community is bound to the ocean in an almost spiritual albeit violent manner. Surfing, an icon of Australian identity, implies belonging to liminal spaces, marks the loss of innocence, and harks back to the colonial past and the settler's distorted perception of the ocean and the land. The deconstruction of the postcolonial country, the subversion of norms, the reconfiguration of the space of the nation, of identities and subjectivities, have become common themes in the literature and the arts of late twentieth- and twenty-first-century Australia. Paul Giffard-Foret addresses the theme of split-identities and the Bhabhan notion of mimicry by revisiting the nature of Albert Namatjira's legacy in light of the retrocession of the artist's copyright, in 2017. Giffard-Foret argues that in post-reconciliation Australia, discourses on race and indigeneity still prompt racist and distorted views of otherness, that Namatjira's western trajectory bears traces of the anxiety linked to the white settler society and the multicultural nation. Showing how Tracy Moffatt refers to Namatjira's work in her semi-autobiographical short-film, Night Cries: A Rural Tragedy, Giffard-Foret argues that postcolonialism remains a problematic concept for Indigenous Australians. The sense of un-belonging to the postcolonial nation is also felt by non-Indigenous others, for instance by Australians of non-English background. Marie Herbillon relies on Ken Gelder and Jane Jacobs's critical work Uncanny Australia 
(1998) to launch a discussion on Michelle de Krester's The Lost Dog (2007); she argues that the legacies of settler history and Indigenous claims disturb the modern nation. By showing that the relation of Australia with Asia tends to rely on the tropes of trauma and gothic haunting, she demonstrates that the sense of belonging and displacement related to history emphasize an unsettling presence, to such an extent that the novel explores "the hydra of modernity itself." The postcolonial paradigm is envisaged through its many intricacies in Maggie Wander's article, in which she analyses colonial histories through the study of Windjarrameru (The Stealing $C^{*} n t \$$ ), the third film of a trilogy which forms the project of the Karrabing Indigenous Corporation. Wander argues that the significance of Indigenous kinship and ancestry, both embedded in the Australian landscape, implies that they are still at the heart of Australia's colonial and essentialist views on non-Anglo subjects, that modernity has, in fact, intensified neocolonial approaches to the land and people. The recognition of cultural otherness within the larger scope of postcolonialism and multiculturalism is reflected in Laura White's piece on Kim Scott's novel That Deadman Dance (2010). Scott's skillful use of language and culture, Noongar vocabulary and ontology, creates what White sees as a framework of ecospectrality, a space where Indigenous and non-Indigenous relations can be re-examined. The retelling of settler history from an Indigenous perspective is a means to re-conceptualize the present and to configure the nation's potential future. White's article, which is part of a current research project, shows how story-telling and the incorporation of the uncanny provide an understanding of local communities and the postcolonial nation Australia, the troubled land in the Asia-Pacific region.

Salhia BEN-MessaHeL University of Toulon 